\title{
THE WILD FOREST REINDEER, RANGIFER TARANDUS FENNICUS, IN THE METSOLA BIOSPHERE RESERVE, NORTHWEST RUSSIA
}

\author{
Danila V. Panchenko ${ }^{1, *} \mathbb{D}$, Antti Paasivaara ${ }^{\circledR D}$, Marja Hyvärinen² ${ }^{\mathbb{D}}$, Yuri A. Krasovskij ${ }^{3} \mathbb{D}^{\mathbb{D}}$ \\ ${ }^{1}$ Institute of Biology of Karelian Research Centre of RAS, Russia \\ *e-mail:danja@inbox.ru \\ ${ }^{2}$ Natural Resources Institute Finland, Finland \\ ${ }^{3}$ Kostomuksha State Nature Reserve, Russia
}

Received: 09.12.2020. Revised: 24.02.2021. Accepted: 01.03.2021.

\begin{abstract}
The existence of the wild forest reindeer (Rangifer tarandus fennicus) in North Europe is under threat. Urgent measures are needed to protect this species. One of the main measures under consideration is the development of a network of Protected Areas (PAs). The Russian part of the Finnish-Russian Friendship Nature Reserve includes a part of the Metsola Biosphere Reserve (MBR). The MBR contains habitats of the Kuhmo Area - Lake Kiitehenjärvi's (Lake Kamennoe) R.t.fennicus subpopulation and it is of great importance for this animal. This area mainly includes summer pastures and rutting and calving areas, while some of these animals also use this area as winter pastures. Tracking animal locations and moving activity with telemetry showed the continuation of seasonal migrations of this animal across the Russian-Finnish border. This confirms the mix of animals living in Finland in the region of Kainuu and animals living in the Republic of Karelia (Russia), as well as the importance of the MBR for maintaining the genetic diversity of R.t. fennicus in both countries. Some of the animals may change their migration patterns and seasonal home ranges, staying in Russia for wintering. There was one case of a collared R.t. fennicus female moving far to the east from the Kuhmo Area - Lake Kiitehenjärvi subpopulation's habitat to the surroundings of the village of Chernyi Porog (Segezhsky district). The genetic purity of R.t. fennicus is influenced by the reindeer husbandry practice in Finland. There are cases of semi-domesticated reindeer (i.e. originating from another Rangifer tarandus subspecies, $R$. $t$. tarandus) occurrence in the MBR, where they were observed in mating (harem) groups of $R$. t. fennicus. Evaluation and analysis of the age and sex structure of the subpopulation in the summer-autumn period in Russia in 2018-2020 showed a small percentage of calves, approximately $12 \%$ of all encountered animals. This may indicate a high predator pressure (e.g. from the side of Canis lupus, Gulo gulo, and Ursus arctos). Over the last three years, out of 16 collared R.t. fennicus females appeared in Karelia, four of them were killed by predators. The location of the habitats near the state border west of the fence, protected with barbed wire (engineered structures) together with control in the PAs (including MBR) ensure the animal protection from poachers. There was only one case of animal death caused by illegal hunting over the last five years. Forest logging may have a significant impact on the future of R.t. fennicus in the MBR. Under conditions of increasing human impact on the surrounding areas, the MBR importance in the R.t. fennicus population conservation also increased. However, to enhance the positive effect, it will be necessary to expand the network of PAs. One of the nearest promising potential PAs is the planned Kalevala Sanctuary.
\end{abstract}

Key words: biodiversity, human impact, migration, Protected Area, rare species, telemetry, ungulates

\section{Introduction}

The active development of vast areas of North Europe and the ecosystem transformation as a result of the mining industry, forestry management, the building of large-scale linear structures (e.g. transport highways, gas pipelines, power lines), and the unregulated development of the tourism industry is a serious threat. It can cause the loss of biodiversity and species' home ranges (Fahrig, 2003; Hanski, 2005; Vistnes \& Nellemann, 2008).

Rangifer tarandus (Linnaeus, 1758) is a native species and an important member of northern circumpolar ecosystems. Archaeological studies proved that this species was already present in Eurasia during the Late Glacial (Kurten, 1968; Vereshchagin, 1979; Rankama \& Ukkonen, 2001).

Currently, Rangifer tarandus is included in the IUCN Red List (VU status) (Gunn, 2016). All its populations in European Russia are un- der protection of the Red Data Book of the Russian Federation (category 3, EN, II) (Order of the Ministry, 2020). The forest subspecies, Rangifer tarandus fennicus (Lönnberg, 1909), is included in the Red Data Book of East Fennoscandia (1998), Red Data Book of the Republic of Karelia (2020) (category 2, EN), and Red Data Book of Finland (NT) (Liukko et al., 2019).

Rangifer $t$. fennicus is a reindeer subspecies native to Finland, the Republic of Karelia (hereinafter - Karelia) and parts of the Arkhangelsk Region, where it inhabits a mosaic of mature coniferous taiga forests, marshlands and lakes (Paasivaara et al., 2018b; Danilov et al., 2020). In various parts of Russia, monitoring of the species distribution showed a significant population decline and an increase in range fragmentation over the last 20 years (Danilov, 2005; Kholodov, 2013; Efimov \& Mamontov, 2014; Panchenko et al., 
2014). In Karelia, this occurred in the mid-to-late 1990s (Danilov, 2003). Currently, according to aerial and terrestrial counts, there are 2300-2400 R.t. fennicus individuals in Karelia, and the largest population is known in the northern districts of Karelia (Loukhy, Kalevala, and Kem). The southern border of the distribution range of this subspecies has noticeably shifted to the north, and it passes through the central part of Karelia (Danilov et al., 2020). In Finland, R.t. fennicus inhabits two large areas, namely Kainuu and Suomenselkä regions. In these areas, the populations include respectively approximately 750 and 1500 individuals (Paasivaara et al., 2018a; LUKE, 2020).

The conservation of the R.t. fennicus population requires comprehensive measures. One of the most important of these is the development of Protected Areas (PAs). The Finnish-Russian Friendship Nature Reserve (FNR) was established for this purpose. In Finland, it includes the territories where the R.t. fennicus disappeared from the country's parts reappeared from the Soviet Union in the 1950s (Vanninen, 1972). Later, a permanent population originated from these animals in Kainuu Province. The establishment of the FNR in the late 1980s made it possible to combine efforts in the conservation of R.t. fennicus and its habitats. The area includes summer pastures of R.t.fennicus of the so-called Kuhmo Area - Lake Kiitehenjärvi subpopulation (Heikura et al., 1985) located on Russian territory. Animals come here from Finland in spring to calve, to spend summer and autumn, and after rutting they return to their winter home ranges in Finland. Many studies devoted to this subpopulation have been performed in Finland (e.g. Heikura et al., 1985; Heikura, 1997; Tuomivaara \& Heikura, 2010), but there has been no such data from Russia for a long time. In 2017, the Metsola Biosphere Reserve was established. It includes the Kostomuksha State Nature Reserve (KNR) and Kalevala National Park (KNP). It unites the areas of the Kuhmo Area - Lake Kiitehenjärvi subpopulation with a new protected status. The MBR was recognised as a special site for testing interdisciplinary approaches to understanding and managing changes in and interactions between social and ecological systems, including conflict prevention and management of biodiversity (UNESCO, 2020). An increasing anthropogenic impact (forest felling, mining) around the PAs highlights the relevance and the need to monitor R.t. fennicus in this Protected Area in Russia.

The purpose of this article was to study the current status and ecological features of the Kuhmo Area - Lake Kiitehenjärvi subpopulation of
R.t. fennicus in the Metsola Biosphere Reserve and to assess the prospects for a continued existence of this subpopulation.

\section{Material and Methods}

The study was performed in the Metsola Biosphere Reserve within an area of $3450.7 \mathrm{~km}^{2}$ in 2018-2020. This territory includes the existing PAs of Kalevala National Park and Kostomuksha State Nature Reserve, as well as the area of the co-operation zone belonging to the Kostomuksha Urban District. The Kostomuksha State Nature Reserve is the Russian part of the Finnish-Russian Friendship Nature Reserve. The Metsola Biosphere Reserve is located in the northwest of Karelia near the Finland-Russia border (Fig. 1) being represented by typical north-taiga habitats.

The dominance of pine (Pinus sylvestris L.) forest in these PAs, a high proportion of old forests, mires of various types, and a hydrographical network (Table 1) make these territories attractive for R.t. fennicus. The area between Kalevala National Park and Kostomuksha State Nature Reserve has been largely transformed because of the forestry industry. The Kostomuksha mining and processing enterprise is located near the town of Kostomuksha.

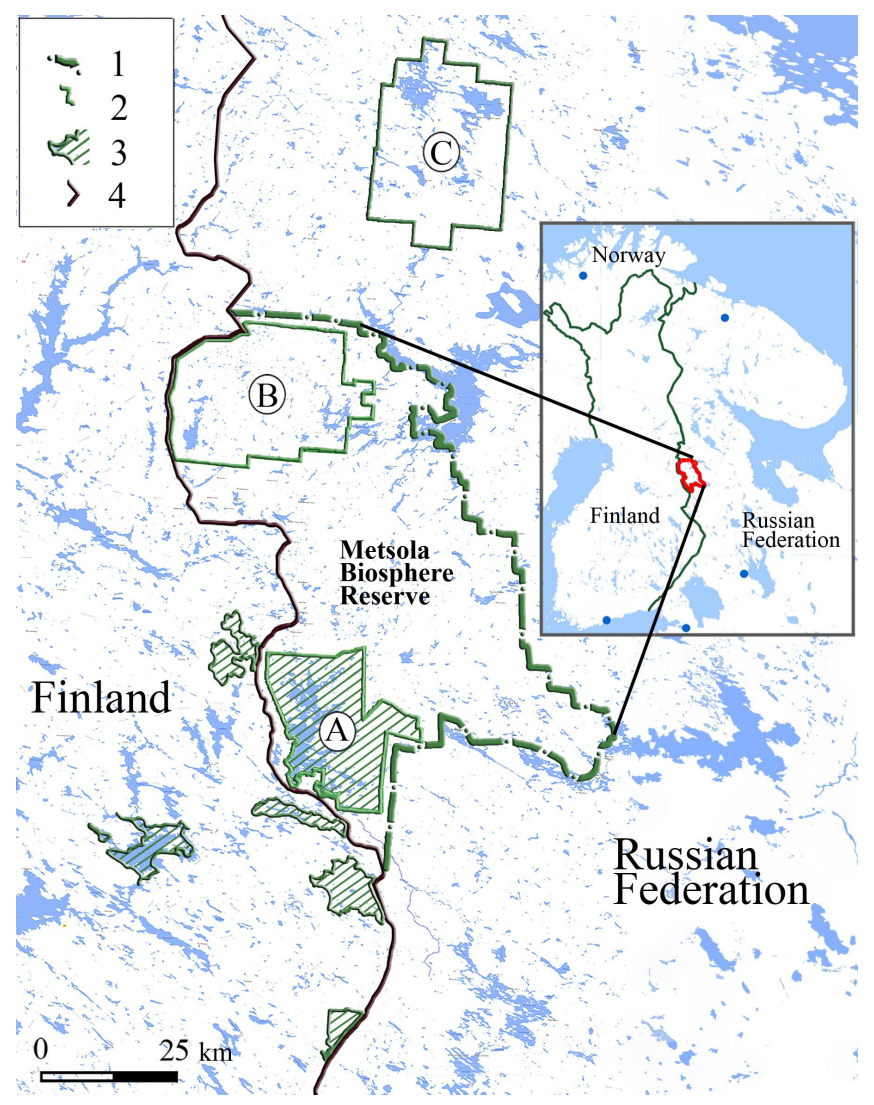

Fig. 1. The location of the study area. Designations: 1 - Metsola Biosphere Reserve border; 2 - borders of Protected Areas, namely Kostomuksha State Nature Reserve (A), Kalevala National Park (B), planned Kalevala Sanctuary (C); 3 - FinnishRussian Friendship Nature Reserve; 4 - Finland-Russia border. 
Table 1. Some characteristics of the areas of Kostomuksha State Nature Reserve and Kalevala National Park according to Kovalevskiy \& Gaydysh (2017)

\begin{tabular}{|c|c|c|c|c|c|c|c|}
\hline \multirow[t]{2}{*}{ Protected Area } & \multirow[t]{2}{*}{$\begin{array}{l}\text { Total area, } \\
\left(\mathrm{km}^{2}\right)\end{array}$} & \multirow{2}{*}{$\begin{array}{l}\text { Total } \\
\text { forest area } \\
\left(\mathrm{km}^{2}\right)\end{array}$} & \multicolumn{2}{|c|}{$\begin{array}{l}\text { Percentage of area covered } \\
\text { by coniferous forests, } \%\end{array}$} & \multirow{2}{*}{$\begin{array}{c}\text { Percentage of } \\
\text { coniferous forest over } \\
120 \text {-year-old of the } \\
\text { total forest area, } \%\end{array}$} & \multirow{2}{*}{$\begin{array}{c}\text { Percentage of water } \\
\text { body systems of } \\
\text { the total area of } \\
\text { Protected Area, \% }\end{array}$} & \multirow{2}{*}{$\begin{array}{l}\text { Percentage of mires } \\
\text { of the total area of } \\
\text { Protected Area, \% }\end{array}$} \\
\hline & & & Pinus sylvestris & Picea abies & & & \\
\hline Kostomuksha State Nature Reserve & 492.6 & 298.6 & 80.3 & 19.0 & 80.6 & 23.8 & 13.3 \\
\hline Kalevala National Park & 743.6 & 505.1 & 81.5 & 17.3 & 87.6 & 12.1 & 23.5 \\
\hline
\end{tabular}

\section{Field surveys}

In winter, we used snowmobile surveys to obtain information about the population size, migration routes, preferred habitats, age and sex structure and behavioural patterns of the subpopulation (Efimov \& Mamontov, 2014). The observation routes covered approximately $80 \%$ of the study area. The total length of the routes was about $1600 \mathrm{~km}$. Winter track counts (WTC) (Formozov, 1932; Priklonsky, 1972; Order of the Ministry, 2012) were carried out on nine permanent routes in the Kostomuksha State Nature Reserve annually in January and February during 1986-2020. During the snowless period, field data were collected on hiking and water routes. The total length of hiking routes was $780 \mathrm{~km}$. All R.t.fennicus traces, the age and sex of the animals and brief descriptions of habitats were reported.

Camera traps were used during field observations throughout the year. They $(n=6)$ were placed on the R.t. fennicus trails in their preferred habitats, resulting in 1340 photographs and videos of R.t. fennicus.

\section{Telemetric tracking}

We used the telemetry data for four collared R.t. fennicus females. Collaring was carried out in Finland with Iridium Plus GPS collars in November - April of 2016-2017 using a helicopter. Animals were immobilised with a DanInject $\mathrm{CO}_{2}$ injection rifle.

We used the movement data for R.t. fennicus females №9 (2016-2020, 8454 locations), №18 (2017-2019, 5107 locations), №54 (2017-2020, 9216 locations), and №55 (2017-2020, 8866 locations). We used tracking data to obtain information on seasonal migrations, summer and winter home ranges, calving and rutting areas, calf survival and mortality. Visual observations of collared animals during the rutting period made it possible to assess the size, age and sex structure of mating groups.

\section{Pasture estimation}

To estimate the supply of Cladonia rangiferina (L.) F.H. Wigg. and Cladonia stellaris (Opiz) Pouzar \& Vězda, the two most widespread lichen species in the diet of R.t. fennicus in Kalevala National Park and Kostomuksha State Nature Reserve, census lines were established using the methods used previously to estimate the winter pastures of R.t. fennicus in Eastern Fennoscandia (Mattila \& Helle, 1978; Annenkov et al., 1989). In total, 39 monitoring lines were established in the study area during 2018-2019, including 29 lines on the mainland and ten lines on the islands of Lake Kamennoe (hereinafter - Lake Kiitehenjärvi) and Lake Sudnozero.

\section{Additional data}

In addition, we used data from surveys of employees of other governmental institutes working on the use and conservation of hunting and forest resources, as well as data from local hunters and residents. The analysis of R.t. fennicus sightings in the Kostomuksha State Nature Reserve covered the period of 1985-2015 $(\mathrm{n}=191)$.

An analysis was carried out using Microsoft Excel, QGIS 2.8.1 (QGIS, 2020), and SAS.Planet (SASGIS, 2020) software. We used the Home Range Analysis and Estimation (HoRAE) toolbox for the free GIS software OpenJUMP (Steiniger \& Hunter, 2013) to calculate 95\% summer and winter home ranges and $50 \%$ core areas. We generated home-range estimates using the kernel method (Worton, 1989; Powell, 2000) and ad-hoc smoothing parameter $\left(\mathrm{h}_{\text {ad-hoc }}\right)(\mathrm{Kie}, 2013)$.

\section{Distribution}

\section{Results}

In the winter period, the study of the R.t. fennicus distribution showed that the KNP includes not only summer but also winter pastures, while the tracks of these animals are reported regularly here in winter. For example, there was a large herd of R.t. fennicus (more than 50 individuals) on Lake Sudnozero in March 2018.

The KNR mainly includes the summer habitats of animals, but some individuals also stay over the winter. In the KNR, signs of R.t. fennicus are not registered yearly on permanent routes during the WTC. In general, R.t. fennicus signs are more often registered in winter in the eastern part of the 
KNR. They probably come from the east from the neighbouring territory of the Muyezersky District.

The MBR cooperation zone belongs to the Kostomuksha Urban District being located between the PAs. This area is characterised by an uneven use by R.t. fennicus. These animals are regularly seen in the Border Security Zone of Russia (up to $20 \mathrm{~km}$ wide), where only restricted human access is allowed. This area is located behind a strong fence with barbed wire running along the border zone on the Karelia's side (engineered structures). Rangifer $t$. fennicus actively use also the eastern part of the cooperation zone on the border with the Muezersky District.

In summer, the R.t. fennicus distribution shows that they are seen anywhere in the Metsola Biosphere Reserve. The observations of R.t. fennicus and their tracks, including females with calves, are regularly registered on islands of large lakes of the KNP and KNR in summer. Survey data allow us to conclude that the islands of Lake Kiitehenjärvi (KNR) and Lake Sudnozero (KNP) are also used for calving.

\section{Cladonia spp. abundance}

The results of the inventory of the forage capacity of the pastures of R.t. fennicus in the KNP and KNR, based on the supply of lichens Cladonia rangiferina and $C$. stellaris, are indicated in Table 2. The average supply values of these lichens were low in both areas.

\section{Habitat usage}

Spring migration to the summer home ranges and subsequent movements within summer pastures happen in the area located between the border of the two countries and the engineered structures on the border. The summer home ranges of the collared R.t. fennicus females were in the MBR (Fig. 2). Female №9 used the area of KNR, and females №18, №54, №55 used mostly the KNP.

There were no traces of R.t. fennicus crossing the engineered structures during the field observation in the KNP. Nevertheless, telemetry data show that such movements still happen occasionally, and collared R.t. fennicus used habitats located east of this fence. Rangifer t. fennicus and other large mammals (e.g. Alces alces (Linnaeus, 1758), Ursus arctos (Linnaeus, 1758)) sometimes cross the fence in the KNR, too. Such cases were also reported during field observations.

The results of the study of the migrations and home ranges of the collared R.t. fennicus females №9, №18, №54, №55, using the area of the MBR during the observation period 2018-
2020, are shown in Table 3. These are displayed also in Fig. 2.

During 2018-2020, 13 out of the 16 collared R.t. fennicus females, spent the summer on the Russian territory, returning to Finland every autumn. For example, this behaviour was reported for R.t. fennicus female №9, which used winter home ranges in Finland and spent the summer in the KNR near Lake Kiitehenjärvi during the observation period (Fig. 2). In contrast, R.t. fennicus females №18, №54, №55 changed their winter home ranges in Finland to winter home ranges in Russia. Until autumn 2017, these animals left for the winter pastures in Finland, but at the beginning of winter 2017, they remained in the summer home range near Lake Levi (KNP). After the rut, they moved northeast. By December 2017, they were found near Lake Okhtanyarvi located $50 \mathrm{~km}$ northeast of their summer pastures. This is the area of the planned Kalevala Sanctuary. Studies of 2020 showed that this area is of great importance for R.t. fennicus throughout the year. It is known that in winter animals move there from the surrounding areas. Early January 2018, for unknown reasons, these three collared R.t. fennicus females in one group began to move and reached their former winter home ranges in Finland, covering a distance of $200 \mathrm{~km}$. In spring, they returned to Karelia, to their summer pastures. Later, two of them (№18 and №55) spent the whole winter of 2018-2019 near Lake Okhtanyarvi. The distance between the new winter home ranges and the previous ranges on the Finnish side was approximately $150 \mathrm{~km}$. Rangifer $t$. fennicus female №55 returned and spent the winter in Finland. However, this female has remained on the Russian side both in summer and in winter since spring 2019. At the summer beginning of 2020 , there was an extraordinary case of movement of collared R.t. fennicus female №88 far beyond the home ranges of the Kuhmo Area - Lake Kiitehenjärvi subpopulation. Starting from the calving sites in Finland, it covered more than $200 \mathrm{~km}$ over 11 days and came to the area of the village of Chernyi Porog (Segezhsky District) on the Russian side, where it was probably killed by Canis lupus (Linnaeus, 1758)

\section{Group size and structure}

The analysis of animal tracks in the KNR showed that the groups of R.t. fennicus observed in winter were small. In 1985-2015, the average number of individuals per group was 5.4 individuals. However, there are also large groups. So, in winter 2018, in the eastern part of the KNR, tracks of a herd of approximately 100 individuals were reported. 
Table 2. The characteristics of Cladonia spp. cover in the KNP and the KNR and adjacent areas

\begin{tabular}{|c|c|c|c|c|c|c|c|c|c|}
\hline \multirow[b]{2}{*}{ Species } & \multicolumn{4}{|c|}{ Cladonia rangiferina } & \multicolumn{4}{|c|}{ Cladonia stellaris } & \multirow[b]{2}{*}{ 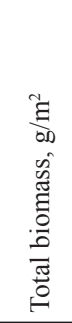 } \\
\hline & 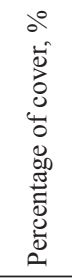 & 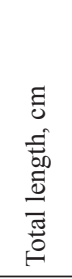 & 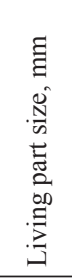 & 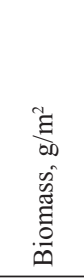 & 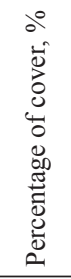 & 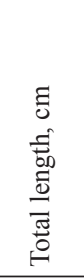 & 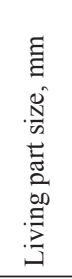 & 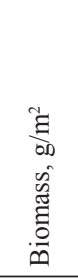 & \\
\hline \multicolumn{10}{|c|}{ Kostomuksha State Nature Reserve } \\
\hline $\mathrm{M}$ & 7.0 & 6.1 & 32.6 & 20.7 & 8.2 & 65.6 & 36.2 & 32.2 & 52.9 \\
\hline $\mathrm{m}$ & 2.14 & 0.64 & 3.22 & 6.6 & 2.59 & 5.61 & 2.95 & 9.9 & 15.6 \\
\hline $\max$ & 40.6 & 12.1 & 51.8 & 121.9 & 44.6 & 140 & 71.3 & 200.0 & 283.1 \\
\hline \multicolumn{10}{|c|}{ Kalevala National Park } \\
\hline $\mathrm{M}$ & 6.6 & 7.1 & 44.5 & 21.1 & 0.2 & 23.7 & 16.9 & 0.8 & 21.9 \\
\hline $\mathrm{m}$ & 1.66 & 0.82 & 5.16 & 5.9 & 0.15 & 12.76 & 9.10 & 0.5 & 6.1 \\
\hline $\max$ & 19.0 & 8.80 & 56.7 & 67.7 & 1.2 & 102.8 & 70.1 & 5.3 & 68.5 \\
\hline
\end{tabular}

Note: $\mathrm{M}$ - arithmetic mean, $\mathrm{m}$ - standard error of the arithmetic mean, max - maximum value.

Table 3. Home range size of collared Rangifer tarandus fennicus females $\left(\mathrm{km}^{2}\right)$

\begin{tabular}{|c|c|c|c|c|c|c|c|}
\hline \multicolumn{4}{|c|}{ Winter } & \multicolumn{4}{|c|}{ Summer } \\
\hline \multirow{2}{*}{ Collar number } & \multirow{2}{*}{ Year } & \multicolumn{2}{|c|}{ Probability volume contour } & \multirow{2}{*}{ Collar number } & \multirow{2}{*}{ Year } & \multicolumn{2}{|c|}{ Probability volume contour } \\
\hline & & $50 \%$ (core) & $95 \%$ (home range) & & & $50 \%$ (core) & $95 \%$ (home range) \\
\hline \multirow{2}{*}{18} & $2017-2018$ & 40.2 & 194.2 & \multirow{2}{*}{18} & 2017 & 88.7 & 396.1 \\
\hline & 2018-2019 & 91.5 & 335.0 & & 2018 & 45.2 & 217.1 \\
\hline \multirow{4}{*}{9} & 2016-2017 & 72.8 & 456.9 & \multirow{3}{*}{9} & 2017 & 17.7 & 62.8 \\
\hline & $2017-2018$ & 92.8 & 439.9 & & 2018 & 13.9 & 67.6 \\
\hline & 2018-2019 & 67.5 & 384.6 & & 2019 & 5.6 & 53.8 \\
\hline & $2019-2020$ & 126.5 & 624.4 & \multirow{4}{*}{54} & 2017 & 52.5 & 219.0 \\
\hline \multirow{3}{*}{54} & 2017-2018 & 88.6 & 351.0 & & 2018 & 42.8 & 264.0 \\
\hline & 2018-2019 & 78.3 & 324.6 & & 2019 & 41.8 & 222.3 \\
\hline & 2019-2020 & 122.6 & 660.3 & & 2020 & 69.5 & 308.1 \\
\hline \multirow{3}{*}{55} & 2017-2018 & 60.8 & 291.6 & \multirow{4}{*}{55} & 2017 & 79.3 & 315.2 \\
\hline & 2018-2019 & 130.7 & 674.0 & & 2018 & 141.4 & 666.3 \\
\hline & 2019-2020 & 138.3 & 562.1 & & 2019 & 121.0 & 544.5 \\
\hline & & & & & 2020 & 64.8 & 311.7 \\
\hline \multicolumn{2}{|l|}{ M } & 92.5 & 441.5 & \multicolumn{2}{|l|}{$\mathrm{M}$} & 56.0 & 260.7 \\
\hline \multicolumn{2}{|l|}{$\mathrm{m}$} & 8.95 & 45.24 & \multicolumn{2}{|l|}{$\mathrm{m}$} & 11.16 & 50.03 \\
\hline \multicolumn{2}{|l|}{$\min$} & 40.2 & 194.2 & \multicolumn{2}{|l|}{$\min$} & 5.6 & 53.8 \\
\hline \multicolumn{2}{|l|}{$\max$} & 138.3 & 674.0 & \multicolumn{2}{|l|}{$\max$} & 141.4 & 666.3 \\
\hline
\end{tabular}

Note: $\mathrm{M}$ - arithmetic mean, $\mathrm{m}$ - standard error of the arithmetic mean, min - minimum value, max - maximum value. The size of winter home ranges on the Russian side (Karelia) is indicated in bold, the one on the Finnish side in normal font.

The MBR has great importance as the area where the rut of R.t. fennicus takes place. In autumn 2018-2020, the field observations in the MBR showed that the size of the rutting groups $(\mathrm{n}=11)$ was on average 8.5 individuals. There were 1.2 adult males and 6.5 females. In October 2020 in the KNP, a semi-domesticated R.t. fennicus female was observed in a harem, i.e. in a mating group of animals. The percentage of calves among all reported sightings and captured by wildlife cameras in the summer-autumn period $(\mathrm{n}=153)$ was only $11.5 \%$.

\section{Threats}

During field observations, tracks of Canis lupus chasing R.t. fennicus were repeatedly registered. Over the past three years, out of 16 collared animals four were killed by C. lupus at summer home ranges in Karelia. Over the past five years, only one case of illegal hunting of R.t. fennicus has been reported.

\section{Distribution}

\section{Discussion}

The habitats in Metsola Biosphere Reserve are of high value for R.t. fennicus. A study of wildlife in these places in the 1970s showed that the number of R.t. fennicus was quite high here. In 1974, a special aerial survey counted 297 individuals of the species in the area of approximately $1500 \mathrm{~km}^{2}$. These data support the establishment of the KNR and adjacent areas (Danilov et al., 1977). Nevertheless, according to these data, various parts of the MBR are used by R.t. fennicus at different degrees in various seasons of the year, for various reasons. 


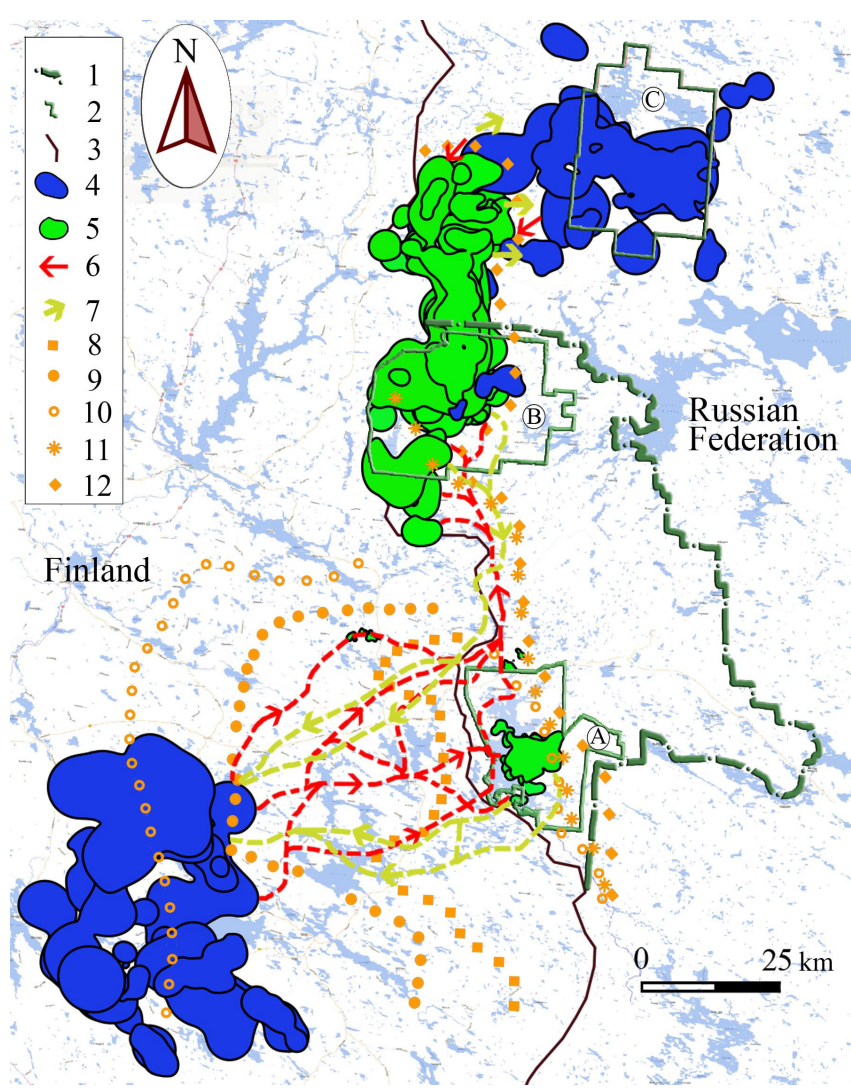

Fig. 2. The home ranges and seasonal movement routes of Rangifer tarandus fennicus. Designations: 1 - Metsola Biosphere Reserve border; 2 - borders of Protected Areas, namely Kostomuksha State Nature Reserve (A), Kalevala National Park (B), planned Kalevala Sanctuary (C); 3 Russia-Finland border; 4 - winter home ranges; 5 - summer home ranges; spring (6) and autumn (7) migration routes of the collared R.t. fennicus female (№9, №18, №54, №55); the borders of R.t. fennicus summer pastures: 8 - 1985, 9 - 1989, $10-1994,11-2008,12-2020$ (according to Heikura, 1997; Tuomivaara \& Heikura, 2010, with additions).

One of the main limitations for this animal is the shortage of suitable winter habitats. For example, the KNR contains mainly summer habitats, which explains the insignificant use of this area by R.t. fennicus in winter. Similarly, some animals remaining in summer habitats over the winter are also reported for other areas in Finland and Karelia (Heikura et al., 1985; Blyudnik et al., 1989; Heikura, 1997). The eastern part of the co-operation zone and the eastern part of the KNR are characterised by lichen pine forest, which is of great importance for R.t. fennicus. These animals are regularly observed in these habitats in winter.

The usage of large lake islands as habitats is a characteristic of R.t. fennicus behaviour in Karelia (Blyudnik et al., 1989; Danilov et al., 2020). To avoid predators and blood-sucking insects, R.t. fennicus spends a lot of time at such places in summer. The territories of KNP and KNR are good examples of this statement.

Anthropogenic disturbance largely determines the usage of these territories by animals outside Protected Areas (e.g. the MBR co-operation zone). The disturbance impact caused by forestry management (Kostomuksha mining and processing enterprise), and hunting is pronounced in this area, while sightings of R.t. fennicus are rare in such an actively developing area. However, in the Border Security Zone, the impact of anthropogenic disturbance is weaker because people hardly visit this area.

\section{Cladonia spp. abundance}

Cladonia spp. are the main winter forage for R.t. fennicus (Sulkava et al., 1983). However, for both investigated areas, the average lichen crop was only $44.9 \mathrm{~g} / \mathrm{m}^{2}$ while in lichen-rich habitats (e.g. Kalevala District near Lake Kunevo), lichen crops were $459.9 \mathrm{~g} / \mathrm{m}^{2}$ (Annenkov et al., 1989). The MBR includes mainly summer habitats of R.t.fennicus, where dwarf shrubs, paludified pine forests, and mires of various types are widely represented, and animals are provided with sufficient summer forage (e.g. grasses, sedges, shrubs, dwarf shrubs). Nevertheless, there are areas with a lichen-rich cover in PAs and in the neighbouring areas. For example, on the eastern border of the KNR in the area of Kalivo Lake, the Cladonia spp. cover reached $235.0 \mathrm{~g} / \mathrm{m}^{2}$ in some survey lines, while in the north-eastern part of the KNR in the area of the River Kamennaya, it reached $283.1 \mathrm{~g} / \mathrm{m}^{2}$. This affects the stay of animals. In winter, regular sightings of animals and their traces are reported in such sites.

\section{Habitat usage}

The study of R.t. fennicus migrations made it possible to obtain new data on the animal's home ranges, rutting locations and routes of seasonal migrations. In the Kuhmo Area - Lake Kiitehenjärvi subpopulation, tracking the animal movements using telemetry has been conducted since the 1980s (Heikura et al., 1985; Pulliainen et al., 1985; Heikura, 1997; Tuomivaara \& Heikura, 2010). The engineered structures running along the border zone on the Karelia side were previously obstacles to the R.t. fennicus migration. This was the reason for the changing migration routes and summer pastures of the animals. The area of summer pastures expanded due to their increase in Finland, while in Russia the area decreased (Heikura, 1997). To present the R.t. fennicus migration from Finnish territory to summer pastures in Karelia has become wider (Fig. 2). In general, about one-third of the collared R.t. fennicus individuals of the Kainuu region comes to the Border 
Security Zone of Russia to calve, using summer habitats in the Metsola Biosphere Reserve. The summer home ranges of this subpopulation in Karelia have been gradually expanding since the 1980s (Fig. 2).

Remarkably, the home ranges of the collared animals were located precisely in the border zone between the actual border and the engineered structures. In addition, the R.t. fennicus traces crossing this line during field research were rarely registered and only in the KNR. It can be assumed that this barrier (i.e. the fence with barbed wire) highly limits the animal movements and the usage of new home ranges. It is known that the building of largescale linear structures restricts ungulate migration (Curatolo \& Murphy, 1986; Wilson et al., 2016; Nandintsetseg et al., 2019; McInturff et al., 2020), and $R$. fennicus is no exception. Additionally, this was the case for R. fennicus on the Kola Peninsula early XX century, when the population was divided into two parts as a result of the railway building (Semenov-Tyan-Shansky, 1977).

The study of the movements of collared R.t. fennicus showed that these animals use vast areas throughout their life cycles (Pulliainen et al., 1983; Heikura et al., 1985; Danilov et al., 2020; Mamontov, 2020) (Table 3). Most of the R.t. fennicus individuals are characterised by a conservative home range selection (Pulliainen et al., 1985, Heikura, 1997). And 13 of the 16 collared females demonstrated the same behaviour, as individual №9. The movements of collared females №18, №54 and №55 were different and showed a close connection between the animals living in both countries. This is very important for the conservation of R.t. fennicus. Genetic diversity largely determines adaptive capacity, as well as population and species viability (Caughley \& Gunn, 1996; Lacy, 1997). The loss of genetic diversity as a result of population decline, fragmentation and the accompanying inbred depression can cause undesirable consequences (Haigh et al., 2006; Roed et al., 2006). In general, in the Metsola Biosphere Reserve, there are three areas, situated in the northern part of the KNP, eastern part of the MBR co-operation zone, and south-eastern part of the KNZ, where R.t. fennicus individuals from various areas in Karelia and in Finland can meet and crossbreed. Therefore, this PA is of great importance for the genetic diversity conservation of R.t. fennicus.

\section{Group size and structure}

Determining the size and sex of populations and age structure of herds makes it possible to better understand the status of the groups and their developmental direction. The small size of groups registered in KNR is probably caused by the small number of animals in wintering area in this part of the MBR for the entire observation period. Accordingly, in 1985-1987, when the number of R.t. fennicus in Karelia was high, in the KNR in winter, the average herd size was 4.5 individuals. In Finland, within the winter home ranges of the Kuhmo Area - Lake Kiitehenjärvi subpopulation, the average herd size was 24 individuals in February (Heikura, 1985). The large group of 100 individuals observed in winter 2018 probably came from the adjacent area of the Muezersky District. The extreme conditions have caused animals to gather together in this large group. So, the snow depth was more than $1 \mathrm{~m}$. Therefore, for animals, it was easier to move and to obtain food in a larger herd.

\section{Threats}

By characterising the population status, it is necessary to note that the number of calves in 2018-2020 was low. This may have been caused by high predator pressure (Canis lupus, Gulo gulo (Linnaeus, 1758), Ursus arctos). This problem is also relevant for the Kainuu region in Finland, where a high density of large predators has become one of the main reasons for the decline in the $R$. fennicus population (Kojola et al., 2004, 2009). In addition, the situation is aggravated by ecotourism-related supplemental feeding sites for large predators located in the core breeding area of R.t. fennicus subpopulation in the Kuhmo area - Lake Kiitehenjärvi near the border and in PAs (Pöllänen, 2020; Penteriani et al., 2021). Apart from the direct influence of C. lupus, the problem of this predator impact on R.t. fennicus population is complicated. So, indirect factors can exacerbate this influence, such as the number of Alces alces, as the main prey of $C$. lupus. With an increase in the number of $A$. alces and, consequently, in the number of $C$. lupus, the number of incidental kills of R.t. fennicus will be increased, too (Kojola et al., 2009). This is noted not only for R.t. fennicus but also for R.t. caribou (Gmelin, 1788) (Serrouya et al., 2017). In Karelia, the $A$. alces number is not so high as it is in Finland. However, there are winter concentrations of A. alces in some parts of MBR (e.g. in the KNP area), and the consequences of a large size of an $A$. alces population may have an indirect impact on R.t. fennicus as well.

In Karelia, another main factor in the R.t. fennicus population decline is poaching. However, these habitats are located near the FinlandRussia border in the restricted zone near the fence. Consequently, in the KNR and the KNP, the ranger's control ensures the best safety of animals from poachers. 
Crossbreeding between R.t. fennicus and semidomesticated reindeer originated from another subspecies, Rangifer tarandus tarandus (Linnaeus, 1758), have adaptations to various snow conditions. The mentioned crossbreeding may be dangerous for the genetic purity of populations. Such a risk is quite high, and sometimes semi-domesticated reindeer escape the reindeer husbandry areas of Finland and migrate south to R.t. fennicus home ranges in Kainuu and to the east to Karelia. Such phenomena were registered in both KNR and KNP.

A serious threat to the R.t. tarandus population is the large-scale forest management (clear cutting). This causes the destruction of pastures, which are of particular importance for these animals during calving and rutting. Additionally, studies of habitat use by $R$. tarandus demonstrated the high value of old coniferous forests with arboreal lichens in winter (Semenov-Tyan-Shansky, 1977; Kumpula et al., 2007). The Biosphere Reserve status does not limit deforestation. It is quite possible that soon the cooperation zone located between the KNP and the KNR will lose its important value for $R$. tarandus. Here, pastures and migration routes of R.t. fennicus coincide with areas where active forest management is underway (Hansen et al., 2013). It is necessary to make adjustments in forest management to identify and protect these areas, which are of great importance for R.t. fennicus. Otherwise, it may become a kind of barrier cutting the connectivity between R.t. fennicus subpopulations by causing the decline of animals' number in these places. In the future, such a habitat fragmentation may cause the loss of the genetic diversity in the R.t. fennicus subpopulation, which will also cause the loss of population viability (Altizer et al., 2003; Fahrig, 2003; Hanski, 2005). Additionally, fragmentation may increase predation pressure due to the focus of Canis lupus influence on R.t. fennicus population, since it becomes more difficult for this ungulate animal to avoid the habitats preferred by $A$. alces and, consequently, encounters with predators (Kojola, 2007).

\section{Conclusions}

Our research of the R.t. fennicus population status in the Metsola Biosphere Reserve in 2018-2020 showed that this area is of great importance for the R.t. fennicus conservation. In the past, R.t. fennicus naturally spread into Finland from these sites. As a result, a stable population was maintaining there. At present, the opposite trend is observed, where some animals from the Finnish populations remain in Karelia, replenishing the number of animals in Russia. There are seasonal migration routes of R.t. fennicus, their summer home ranges, and rutting and calving places in the MBR. They largely provide maintenance and recovery of the threatened population. The mix of the R.t. fennicus populations of Finland and Karelia is an indispensable condition for the genetic diversity conservation of R.t. fennicus and the further prosperous existence of this endemic North European animal. Therefore, the MBR greatly supports such population mixing.

The obtained results show that large carnivores have a great influence on the R.t. fennicus groups inhabiting these areas. This is one of the main natural factors negatively impacting the growth of the R.t. fennicus population. It is necessary to pay more attention to this issue and try determining the location of Canis lupus packs in the MBR, as well as take measures to reduce the $C$. lupus numbers in the MBR co-operation zone where it is allowed from a $C$. lupus conservation viewpoint. Predation is a difficult issue in Finland, where the situation is complicated by the fact that some IUCN conservation criteria are applied to maintaining vital multispecies predatorprey communities in highly managed boreal forest landscapes. These criteria lead to a high rank of the conservation status of large predators and apparent competition between high A. alces and low R.t. fennicus density. Supplemental feeding of predators for ecotourism enhances the problem. In future, the forestry industry in the MBR cooperation zone and in neighbouring areas may become a serious threat, causing a decrease in the number of R.t. fennicus in these areas.

In general, it is necessary to continue and expand the research in the MBR. It is very important that the connectivity of R.t. fennicus populations in Finland and Russia should be supported by the functioning of the Finnish-Russian Friendship Nature Reserve and the MBR. The continuation of active co-operation between researchers from Russia and Finland is also of great importance to study and protect the R.t. fennicus populations. It is especially significant to investigate animal movements during spring and autumn migrations. These data will make it possible to clarify the relationships between the groups of animals living at both sides of the Finnish-Russian border. Finnish researchers have data on the R.t. fennicus migrations across the Russia-Finland border into the MBR. However, it is also important to conduct a detailed study of the R.t. fennicus movements into the surrounding areas. It will help for a better understanding of the connections of the Kuhmo Area - Lake Kiitehenjärvi subpopulation with animals living north, east and south of the MBR, including the planned Kalevala Sanctuary. The establishment of this projecting PA will complement the 
network of PAs, which are of high significance for R.t. fennicus population conservation.

\section{Acknowledgements}

We are grateful to S.V. Tarkhov (Director of the Kostomuksha State Nature Reserve, Russia) and I.S. Gaidysh (Deputy Director for research of the Kostomuksha State Nature Reserve, Russia) for their help in organising the field work. The studies were carried out under state order to KarRC RAS (0218-2019-0080) and was supported by the Russian Foundation for Basic Research (grant №18-05-00646).

\section{References}

Altizer S., Harvell D., Friedle E. 2003. Rapid evolutionary dynamics and disease threats to biodiversity. Trends in Ecology and Evolution 18(11): 589-596. DOI: 10.1016/j.tree.2003.08.013

Annenkov V.G., Blyudnik L.V., Danilov P.I., Markovsky V.A., Heikura K. 1989. Comparative characteristics of winter pastures of forest reindeer in Eastern Fennoscandia. In: Forest reindeer of Fennoscandia. Petrozavodsk: Karelian branch of AS USSR. P. 3546. [In Russian]

Blyudnik L.V., Danilov P.I., Markovsky V.A., Heikura K., Annenkov V.G. 1989. About daily and seasonal movements of forest reindeer in Karelia ASSR (1986-1988). In: Forest reindeer of Fennoscandia. Petrozavodsk: Karelian branch of AS USSR. P. 47-54. [In Russian]

Caughley G., Gunn A. 1996. Conservation biology in Theory and Practice. Cambridge: Blackwell Science. 453 p.

Curatolo J.A., Murphy S.M. 1986. The effects of pipelines, roads, and traffic on the movements of caribou, Rangifer tarandus. Canadian Field-Naturalist 100(2): 218-224.

Danilov P.I. 2003. Wild forest reindeer (Rangifer tarandus fennicus Lönnb.) in the Russian European North. Rangifer Report 7: 37.

Danilov P.I. 2005. Game animals of Karelia: ecology, resources, management and conservation. Moscow: Nauka. 340 p. [In Russian]

Danilov P.I., Zimin V.B., Ivanter T.V., Lapshin N.V., Markovsky V.A., Annenkov V.G. 1977. Faunistic review of terrestrial vertebrates. In: Biological resources of the Kostomuksha district, ways of development and protection. Petrozavodsk: Karelian branch of AS USSR. P. 109-127. [In Russian]

Danilov P.I., Panchenko D.V., Tirronen K.F. 2020. The reindeer of Eastern Fennoscandia. Petrozavodsk: KRC RAS. 187 p. [In Russian]

Efimov V.A., Mamontov V.N. 2014. Wild reindeer monitoring in the taiga zone of the Arkhangelsk region. Herald of Game Management 11(2): 166-170. [In Russian]

Fahrig L. 2003. Effects of Habitat Fragmentation on Biodiversity. Annual Review of Ecology, Evolution, and Systematics 34(1): 487-515. DOI: 10.1146/annurev. ecolsys.34.011802.132419

Formozov A.N. 1932. The formula for the accounting of mammals by their tracks. Zoologicheskii Zhurnal 11(2): 66-69. [In Russian]
Gunn A. 2016. Rangifer tarandus. In: The IUCN Red List of Threatened Species. Available from https://www.iucnredlist.org/species/29742/22167140

Haigh J., Keay M.G., Gerwing V., Erdenbaatar J., Nansalmaa M. 2006. Disease Problems in Mongolian Reindeer. In: $A d-$ vances in deer biology: deer in a changing world. Prague: Research Institute of Animal Production. P. 73-74.

Hansen M.C., Potapov P.V., Moore R., Hancher M., Turubanova S.A., Tyukavina A., Thau D., Stehman S.V., Goetz S.J., Loveland T.R., Kommareddy A., Egorov A., Chini L., Justice C.O., Townshend J.R.G. 2013. High-resolution global maps of $21^{\text {st }}$-century forest cover change. Science 342(6160): 850-853. DOI: 10.1126/science. 1244693

Hanski I. 2005. The shrinking world: ecological consequences of habitat loss. Oldendorf: International Ecology Institute. $307 \mathrm{p}$.

Heikura K. 1997. Some aspects on the recent changes in the Kuhmo - Lake Kiitechensjarvi subpopulation of the wild forest reindeer (Rangifer tarandus fennicus Lönnb). In: T. Lindholm, R. Heikkilä, M. Heikkilä (Eds.): Ecosystems fauna and flora of the Finnish-Russian Nature Reserve Friendship. Helsinki: Finnish Environment Institute. P. 203-211.

Heikura K., Pulliainen E., Danilov P., Erkinaro E. 1985. Wild forest reindeer (Rangifer tarandus fennicus Lönnb). Its historical and recent occurrence and distribution in Finland and Karelian ASSR (USSR) with special reference to the development and movement of the Kuhmo (Finland) - Kamennoje ozero subpopulation. Aquilo, Series Zoologica 23: 22-45.

Kholodov E.V. 2013. Wild forest reindeer in Vodlozero National Park. Proceedings of State Petrozavodsk University 2(131): 33-35. [In Russian]

Kie J.G. 2013. A rule-based ad hoc method for selecting a bandwidth in kernel home-range analyses. Animal Biotelemetry 1: 13. DOI: $10.1186 / 2050-3385-1-13$

Kojola I. 2007. The impact of large carnivores on wild forest reindeer population in Finland. Suomen Riista 53: 42-47.

Kojola I., Huitu O., Toppinen K., Heikura K., Heikkinen S., Ronkainen S. 2004. Predation on European wild forest reindeer (Rangifer tarandus) by wolves (Canis lupus) in Finland. Journal of Zoology 263(3): 229-235. DOI: $10.1017 / \mathrm{S} 0952836904005084$

Kojola I., Tuomivaara J., Heikkinen S., Heikura K., Kilpeläinen K., Keränen J., Paasivaara A., Ruusila V., Heikura K. 2009. European Wild Forest Reindeer and Wolves: Endangered Prey and Predators. Annales Zoologici Fennici 46(2): 416-422. DOI: 10.5735/086.046.0602

Kovalevskiy Y., Gaydysh I. 2017. Extract from cadastral data in the Kalevala National Park and Kostomuksha State Nature Reserve for the period of 2013-2016. Available from https://www.kostzap.com/ [In Russian]

Kumpula J., Colpaert A., Anttonen M. 2007. Does forest harvesting and linear infrastructure change the usability value of pastureland for semi-domesticated reindeer (Rangifer tarandus tarandus)?. Annales Zoologici Fennici 44: 161-178.

Kurten B. 1968. Pleistocene Mammals of Europe. Chicago: Aldine. 317 p. 
Lacy R.C. 1997. Importance of genetic variation to the viability of mammalian populations. Journal of Mammalogy 78(2): 320-335. DOI: $10.2307 / 1382885$

Liukko U.M., Henttonen H., Kauhala K., Kojola I., Kyheröinen E.M., Pitkänen J. 2019. Mammals. In: E. Hyvärinen, A. Juslén, E. Kemppainen, A. Uddström, U.M. Liukko (Eds.): The 2019 Red List of Finnish Species. Helsinki: Ministry of Environment and Finnish Environment Institute. P. 571-575.

LUKE. 2020. Finnish forest reindeer. Available from https:// www.luke.fi/en/natural-resources/game-and-hunting/ finnish-forest-reindeer/

Mamontov V.N. 2020. Individual daily habitats and daily movements of wild forest reindeer (Rangifer tarandus fennicus Lönnb.) in the east part of the Republic Karelia. Herald of Game Management 17(1): 4-10. [In Russian]

Mattila E., Helle T. 1978. Winter pasture inventory of the middle reindeer management area. Folia Forestalia 358: $1-31$.

McInturff A., Xu W., Wilkinson C.E., Dejid N., Brashares J. 2020. Fence Ecology: Frameworks for Understanding the Ecological Effects of Fences. BioScience 70(11): 971-985. DOI: 10.1093/biosci/biaa103

Nandintsetseg D., Bracis C., Olson K., Böhning-Gaese K., Calabrese J., Buyanaa C., Fagan W., Fleming C., Heiner M., Kaczensky P., Leimgruber P., Dalannast M., Stratmann T., Mueller T. 2019. Challenges in the conservation of wide-ranging nomadic species. Journal of Applied Ecology 56(8): 1916-1926. DOI: $10.1111 / 1365-2664.13380$

Order of the Ministry of Natural Resources and Ecology of the Russian Federation of 24 March 2020 No.162 «On approval of the List of wildlife objects listed in the Red Book of the Russian Federation». Official Internet portal of legal information. 2020. Available from http://publication.pravo.gov.ru/Document/ View/0001202004020020/

Order of the Ministry of Natural Resources of the Russian Federation of 11 January 2012 No.1 «On approval of the Methodological Instructions on the implementation by the executive authorities of the constituent entities of the Russian Federation of the transferred authority of the Russian Federation to carry out state monitoring of hunting resources and their habitats by winter track count». Electronic Fund of legal and regulatory and technical documentation. 2012. Available from http://docs.cntd.ru/ document/902325152/

Paasivaara A., Gavrilov M., Juntunen A., Kokko S., Korhonen L., Ovaskainen R., Timonen P. $2018 \mathrm{a}$. Wild forest reindeer counts 2017. In: Game animals counts 2017. Helsinki: Natural Resources Institute. P. $18-23$.

Paasivaara A., Kaartinen S., Puoskari V., Rytkönen S, Pusenius J. 2018b. Summer habitats of wild forest reindeer (Rangifer tarandus fennicus Löb.) in Finland - A preliminary predictive model. In: Dynamics of game animals populations in Northern Europe. Petrozavodsk: KarRC RAS. P. 207-208.
Panchenko D.V., Danilov P.I., Tirronen K.F., Blyudnik L.V. 2014. On the problem of the status of reindeer in the White sea area. Herald of Game Management 11(2): P. 171-175. [In Russian]

Penteriani V., Lamamy C., Kojola I., Heikkinen S., Bombieri G., Delgado M. 2021. Does artificial feeding affect large carnivore behaviours? The case study of brown bears in a hunted and tourist exploited subpopulation. Biological Conservation 254: 108949. DOI: $10.1016 /$ j.biocon.2021.108949

Pöllänen A. 2020. Variation in the survival of wild forest reindeer (Rangifer tarandus fennicus) caused by large carnivores. MSc Thesis. Oulu: University of Oulu. 34 p.

Powell R.A. 2000. Animal home ranges and territories and home range estimators. In: L. Boitani, T. Fuller (Eds.): Research techniques in animal ecology: controversies and consequences. New York: Columbia University Press. P. 65-110.

Priklonsky S.G. 1972. Instructions for the winter track count. Moscow: Kolos. 16 p. [In Russian]

Pulliainen E., Sulkava S., Erkinaro E., Heikura K., Lindgren E. 1983. Seasonal movements of the wild forest reindeer (Rangifer tarandus fennicus) in eastern Finland. Acta Zoologica Fennica 175: 15-16.

Pulliainen E., Danilov P., Heikura K., Erkinaro E., Sulkava S., Lindgren E. 1985. The familiar area hypothesis and movement pattern of wild forest reindeer in Karelia, Northern Europe. Rangifer 6(2): 235-240. DOI: 10.7557/2.6.2.652

QGIS. 2020. QGIS A Free and Open Source Geographic Information System. Available from: https://ggis.org/ru/site/

Rankama T., Ukkonen P. 2001. On the early history of the wild reindeer (Rangifer tarandus L.) in Finland. Boreas 30(2): 131-147. DOI: 10.1111/j.1502-3885.2001.tb01218.x

Red Data Book of East Fennoscandia. Helsinki: Finnish Environment Institute, 1998. $351 \mathrm{p}$.

Red Data Book of the Republic of Karelia. Belgorod: Constanta, 2020. 448 p. [In Russian]

Roed K.H., Haigh J.C., Gerving V., Keay M. 2006. Genetic distinctiveness of isolated and threaten tsaan reindeer. In Advances in deer biology: deer in a changing world. Prague: Research Institute of Animal Production. P. 86.

SASGIS. 2020. SAS.Planet. Available from http://www.sasgis.org/sasplaneta/

Semenov-Tyan-Shansky O.I. 1977. Reindeer. Moscow: Nauka. 94 p. [In Russian]

Serrouya R., McLellan B.N., van Oort H., Mowat G., Boutin S. 2017. Experimental moose reduction lowers wolf density and stops decline of endangered caribou. PeerJ 5: e3736. DOI: 10.7717/peerj.3736

Steiniger S., Hunter A.J.S. 2013. A scaled line-based kernel density estimator for the retrieval of utilization distributions and home ranges from GPS movement tracks. Ecological Informatics 13: 1-8. DOI: 10.1016/j. ecoinf.2012.10.002

Sulkava S., Erkinaro E., Heikura K., Lindgren E., Pulliainen E. 1983. Food of the wild forest reindeer, Rangifer tarandus fennicus, in Finland in winter and summer 1981. Acta Zoologica Fennica 175: 17-19. 
Tuomivaara J., Heikura K. 2010. Development of the number of individuals in the Kuhmo-Kamennoje ozero subpopulation of the wild forest reindeer (Rangifer tarandus fennicus Lönnb.) from 1950's to 2010 with special reference to the passed decade. Herald of Game Management 7(2): 229-233.

UNESCO. 2020. Metsola Biosphere Reserve. Available from http://www.unesco.org/new/en/natural-sciences/ environment/ecological-sciences/biosphere-reserves/ europe-north-america/russian-federation/metsola/

Vanninen E. 1972. Kuhmon peurahistoriikki. Suomen Luonto 31: 231-232.

Vereshchagin N.K. 1979. Ungulates of the North-West of Russia in the Quaternary period. In: Ungulates of the
North-West of the USSR. Leningrad: Nauka. P. 5-62. [In Russian]

Vistnes I., Nellemann C. 2008. The matter of spatial and temporal scales: a review of reindeer and caribou response to human activity. Polar Biology 31(4): 399-407. DOI: 10.1007/s00300-007-0377-9

Wilson R.R., Parrett L.S., Joly K., Dau J.R. 2016. Effects of roads on individual caribou movements during migration. Biological Conservation 195: 2-8. DOI: 10.1016/j. biocon.2015.12.035

Worton B.J. 1989. Kernel methods for estimating the utilization distribution in home-range studies. Ecology 70(1): 164-168. DOI: $10.2307 / 1938423$

\title{
ЛЕСНОЙ СЕВЕРНЫЙ ОЛЕНЬ (RANGIFER TARANDUS FENNICUS) В БИОСФЕРНОМ РЕЗЕРВАТЕ МЕТСОЛА (СЕВЕРО-ЗАПАД РОССИИ)
}

\author{
Д. В. Панченко ${ }^{1, *} \mathbb{D}$, А. Паасивара ${ }^{2} \mathbb{D}$, М. Хювяринен ${ }^{2} \mathbb{D}$, Ю. А. Красовский ${ }^{3} \mathbb{D}$ \\ ${ }^{1}$ Институт биологии Карельского научного иентра РАН, Россия \\ *e-mail:danja@inbox.ru \\ ${ }^{2}$ Институт природных ресурсов Финляндии, Финляндия \\ ${ }^{3}$ Государственный природный заповедник «Костомукшский», Россия
}

Существование Rangifer tarandus fennicus на севере Европы - под угрозой, и необходимы срочные меры для его сохранения. Одна из главных - это создание сети особо охраняемых природных территорий (ООПТ). Биосферный резерват «Метсола» (БРМ), в пределах которого расположена российская часть заповедника «Дружба», включает в себя местообитания кухмо-каменноозерской группировки R.t. fennicus и имеет для него большое значение. Здесь располагаются преимущественно летние участки обитания, места отела и гона R.t. fennicus, однако часть особей использует эту территорию и как зимние местообитания. Слежение за перемещениями особей с помощью телеметрии подтверждает продолжение сезонных миграций R.t. fennicus через границу. Это подтверждает связь животных, обитающих в Финляндии в регионе Кайнуу и Республике Карелия, и важность БРМ для сохранения общности и генетического разнообразия R.t. fennicus двух стран. Некоторые особи могут менять пути миграций и сезонные местообитания, оставаясь на зиму на территории России. Отмечен случай перемещения меченой важенки далеко на восток за пределы обычных мест обитания кухмо-камменоозерской группировки в район д. Черный порог (Сегежский район Карелии). На генетическую чистоту R.t. fennicus оказывает влияние домашнее оленеводство в Финляндии. Регистрируются случаи заходов одомашненных особей R.t. fennicus на территорию заповедника «Дружба», и их присутствие в гаремных группах R.t. fennicus. Наблюдения за половозрастной структурой группировки R.t. fennicus в летне-осенний период на российской территории в 2018-2020 гг. показали низкую долю сеголетков (около 12\%). Это может указывать на высокий пресс хищников (например, Canis lupus, Gulo gulo, Ursus arctos). За последние три года из 16 меченых важенок, приходящих в Карелию, четыре особи погибли по причине хищничества. Приграничное положение мест обитаний, находящихся за полосой инженерно-технических сооружений, и контроль угодий на ООПТ, входящих в БРМ, обеспечивают лучшую сохранность R.t.fennicus от браконьеров. За последние пять лет зарегистрирован только один случай гибели от нелегальной охоты. Сильное влияние на будущее популяции R.t. fennicus БРМ могут оказать рубки леса. В условиях усиления антропогенного влияния значение БРМ в сохранении R.t. fennicus возросло. Однако для усиления положительного эффекта необходимо расширение сети ООПТ, и одной из ближайших перспективных является планируемый заказник «Калевальский».

Ключевые слова: антропогенное влияние, биоразнообразие, копытные, миграции, особо охраняемая природная территория, редкий вид, телеметрия 